\title{
Correlation between Vertebral Length (OS.Vertebralis) and Body Height in Indonesian People
}

\author{
Ahmad Yudianto, ${ }^{1}$ Ariyanto Wibowo ${ }^{2}$ \\ ${ }^{1}$ Department of Forensic and Medicolegal Medicine Faculty of Medicine Universitas Airlangga/Dr. Soetomo \\ General Hospital Surabaya, Indonesia, ${ }^{2}$ Magister of Forensic Science Universitas Airlangga Surabaya, Indonesia
}

\begin{abstract}
Identification of unidentified living and dead human bodies can be carried out for the purposes of criminal investigation and other police duties. Among the most important information to identify one's identity is the one obtained from the results of measuring the victim's height. Thus, it is necessary to determine the height of a body of unidentified identity during the examination. To date, the correlation between the body height and vertebrae has not been widely known. The purpose of this present study was to determine the correlation between the body height and the length of the vertebrae. The study was conducted in Dr. Soetomo General Hospital from January to July 2018. This was an observational analytical study on 57 samples consisting of 32 male and 25 female samples. Results indicated that the correlation between the vertebral length (thoracic vertebra (X1) and lumbar vertebra (X2)) and the body height as determined using the following equations: $\mathrm{Y}=47.428+2.991 \mathrm{X} 1+2.13 \mathrm{X}_{2} \mathrm{~cm}(\mathrm{male})$; $\mathrm{Y}=-32.496+3.800 \mathrm{X}_{1}+5.549 \mathrm{X}_{2} \mathrm{~cm}$ (female); show that there are quite strong when analyzed using $\mathrm{t}$-test $(\mathrm{r}=0.799$ for male and $r=0.908$ for female). In conclusions, this regression formula can be used in estimating the height found only in bones without other long bones.
\end{abstract}

Key words: Correlation, height, vertebrae

\section{Korelasi Antara Panjang Tulang Belakang (OS.Vertebralis) dengan Tinggi Badan pada Orang Indonesia}

\begin{abstract}
Abstrak
Identifikasi tubuh manusia yang tidak dikenal, baik yang masih hidup maupun yang sudah meninggal dapat dilakukan bagi kepentingan penyidikan perkara pidana dan bagi tugas kepolisian yang lain. Salah satu informasi yang sangat penting dapat digunakan untuk melacak identitas seseorang adalah informasi yang didapatkan dari hasil pengukuran tinggi badan korban. Oleh karena itu, pada waktu dilakukan pemeriksaan jenasah yang tidak diketahui identitasnya, perlu ditentukan tinggi badannya. Sejauh ini korelasi tinggi badan dengan panjang ruas tulang belakang belum banyak diketahui. Penelitian bertujuan mengetahui korelasi tinggi badan dengan panjang ruas tulang belakang. Penelitian dilakukan di RSUD Dr. Soetomo periode Januari sampai Juli 2018. Metode penelitian yang digunakan observasional analitik yang dilakukan pada 57 sampel dengan rincian 32 sampel pria dan 25 sampel wanita. Hasil penelitian, korelasi panjang tulang belakang (vertebra torakalis $\left(\mathrm{X}_{1}\right)$ dan vertebra lumbalis $\left(\mathrm{X}_{2}\right)$ dengan tinggi badan dengan uji t didapatkan persamaan regresi: $Y=47,428+2,991 \mathrm{X}_{1}+2,13 \mathrm{X}_{2} \mathrm{~cm}$ (laki-laki); $\mathrm{Y}=-32,496+3,800 \mathrm{X}_{1}+5,549 \mathrm{X}_{2} \mathrm{~cm}$ (wanita). Nilai korelasi yang cukup kuat, $\mathrm{r}$ untuk laki-laki: 0,799 sedangkan untuk wanita 0,908. Simpulan, Formula regresi ini dapat digunakan untuk memperkirakan ketinggian yang ditemukan hanya pada tulang tanpa tulang panjang lainnya.
\end{abstract}

Kata kunci: Korelasi, os.vertebra, tinggi badan 


\section{Introduction}

Identification of unknown human bodies, both living and dead, can be carried out for the benefit of criminal investigation and other police duties, for example during natural disasters, accidents resulting in mass casualties, and other catasthropies.

Knowledge on the identity of the victim enables the investigator to continue with the investigation in a more directed manner to reveal the truth behind the case. This is based on the notion in criminology that there is generally a relationship between the perpetrator and the victim. Identification action is a part of the investigator's duties and responsibilities; however, doctor's expertise is very much needed in the effort of identification. ${ }^{1}$

One of the most important information that can be used to trace one's identity is information obtained from measuring the victim's height. Therefore, at the time of the examination of an unknown body, it is necessary to determine its height. $^{2}$

When identification is perform on a nonintact body, height can be determined by using the size of long bones including, among others, femur (os femur), shin (os tibia), upper arm bone (humeral os), lever bone (os radius and ulna), and the spine (vertebral collumna). However, there has not been any widely published publication on the correlation between height and spine in Indonesia.

In some murder cases, the body of the victim is cut into several parts, or mutilated. This mutilation action aims to remove the traces or identity of the victim to prevent the victim from being recognized.

Medical identification in principle is performed through stages of post mortemantemortem data collection and comparison of both data. Post mortem data are obtained from the examination of the body, body parts or skeletons include race, sex, age, height, weight, parturity (in women), hair, eyes, and skin. ${ }^{3}$

Body height is a data that will be collected in an examination of an unknown body. In cases with intact bodies, height measurement is not a problem. However, when the body is not intact, such as in the case of mutilation, or it is found in the form of a skeleton corpse, the height must be estimated using certain methods. There are several methods that are generally used for estimating height, including tables, multiplication factors, proportions or regression formulas, which show the relationship between height and length of the long bones or vertebrae. ${ }^{3}$

Determination of height becomes a very important in issue to consider when the body is not intact or only in the form of a skeleton or only a part of the body. Measurement of height can be performed by measuring long bones including the femur, shin, and arm bones.

Height measurement tecnique using the spine is first reported by Topmaid-Rollet (1923) and by Donald R Jason. ${ }^{5}$

Collumna vertrebralis is a part of the bones that support a person's body shape. It consists of the neck bone (cervical vertebrae), spine (thoracal vertebrae), waist bone (lumbar vertebrae), pelvis (os sacrum), and coccyx (os coccygeus). the five groups of bones consist of bone segments connected by cartilage, all of which follow the direction of the axis of the body. Therefore, these bones can reflect a person's height.

Collumna vertebralis usually consists of 33 bone segments, i.e. cervicalis, thoracalis and lumbar vertebra segments of bone that are separated from each other and movable and while Os Sacrum and Os Coccygeus are united bone segments. The cervical, thoracalis, and lumbar vertebrae are separated $\mathrm{f}$ by cartilages (intervertebral discs). ${ }^{6}$

\section{Methods}

This study was performed on unidentified dead bodies sent in the Forensic Medicine and Medicolegal Installation of Dr. Soetomo Surabaya during the period of January 2018 to December 2019 for post-mortem visum et repertum pursuant to the Article 133 of the Criminal Procedure code. Bodies were included when they met the following inclusion criteria: Native Indonesian and, aged 17-30 years old. The age criteria was selected because human in 17-30 years old has reached the maximum bone development period. Bodies were excluded when they were foreigners and had Ethical clearance for this study was obtained from the Ethics Committee of Dr. Soetomo Hospital Surabaya.

This was an observational study using alternative method for body i. The measurement methods used were different between the thoracal vertebrae and lumbar spine. For the thoracal vertebrae, the measurement was performed from the upper border of the thoracic vertebrae I to the lower border of the XII thoracic vertebra while for the lumbar spine the measurement was performed from the upper 
A. Yudianto \& A. Wibowo: Correlation between Vertebral Length (OS.Vertebralis) and Body Height in Indonesian People

Table Sample Description

\begin{tabular}{lcccccc}
\hline & \multicolumn{3}{c}{ Male (n = 32) } & \multicolumn{3}{c}{ Female (n = 25) } \\
\cline { 2 - 7 } & TB & V.Th & V.Lm & TB & V.Th & V.Lm \\
\hline Mean & 165.94 & 27.13 & 17.54 & 151.76 & 25.08 & 16.02 \\
Minimum & 153 & 25.3 & 15.9 & 137 & 23.4 & 14.6 \\
Maximum & 178 & 29.9 & 18.8 & 168 & 26.7 & 17.6 \\
SD & 5.25 & 1.09 & 0.71 & 7.71 & 0.89 & 0.83 \\
\hline
\end{tabular}

Notes: TB: Height body; V.Th: vertebrae thoracicu; V.Lm: vertebrae lumbalis

border of the lumbar vertebra I to the lower border of the lumbar vertebrae.

\section{Results}

The total number of bodies examined in this study was 57 bodies which were group by sex as shown in Table.

The relationship between the thoracalis vertebra (X1) and lumbar (X2) lengths and height in men and women was determined using a regression equation based on $\mathrm{T}$ test:

$$
\begin{gathered}
Y=47.428+2.991 X_{1}+2.13 X_{2} \mathrm{~cm} \text { (Male) } \\
Y=-32.496+3.800 X_{1}+5.549 X_{2} \mathrm{~cm} \text { (Female) }
\end{gathered}
$$

The relationship between the thoracal vertebra length and height in men and women was determined using a regression equation based on T test:

$$
\begin{gathered}
\mathrm{Y}=67448+3.63 \mathrm{X}_{1} \mathrm{~cm} \text { (Male) } \\
\mathrm{Y}=-29.491+7.228 \mathrm{X}_{1} \mathrm{~cm} \text { (Female) }
\end{gathered}
$$

Whereas the relationship between lumbar vertebra length and height in men and women was determined using a regression equation based on T test:

$$
\begin{gathered}
Y=90.813+4.284 \mathrm{X}_{2} \mathrm{~cm} \text { (Male) } \\
Y=18.848+8.287 \mathrm{X}_{2} \mathrm{~cm} \text { (Female) }
\end{gathered}
$$

\section{Discussion}

Determination of the identity of an unknown victim is performed by having a doctor check the victim's body or a part of the victim's body to obtain post mortem data. Post mortem data collection is important and plays a huge role in the process of identifying victims. ${ }^{7}$
The study on the linear regression formula for height and bone length has been performed everal decades ago. Human bone growth is believed to be influenced by several internal and external factors such as genetics, gender, nutritional status, and environment. Therefore, it is necessary to do new studies on these factors because the present nutritional status and $t$ environment very different from those in the past.

Data that can be used in the identification process include height, which is an important data that has to be determined. In intact body, the measurement of height is not difficult. However, if the body is not intact, for example in the case of mutilation or fire, certain methods are needed to determine the height of the victim including methods that use measurement of long bones, or certain bone parts. ${ }^{8}$

Determination of height based on the measurement of the spine (vertebral collumna) is one of the methods that are commonly used to estimate a person's height based on the size of the bones. ${ }^{9}$

Height is influenced by race, gender, generation, and age. In general, height shrinkage occured after a person is over 30 years old is 0.06 $\mathrm{cm} /$ year due to thinning of joints, thinning of intervertebral discs, and vertebral obstruction. ${ }^{3}$

The accuracy of estimating height with the help of the spine is strongly influenced by several factors, including: race, age, and gender. A study has been conducted by by Todmad (1923) and Rosselt on white Americans and blacks using a formula. However, for Indonesian race, this formula might be inappropriate. ${ }^{10}$

This present study was conducted on Indonesian people, specifically in Surabaya using a linear regression analysis on thoracal and lumbar vertebral length to determine the height of the person.

From the results, it was revealed that the difference between the height and vertebral 
collumna length in women (r: 0.908) has a stronger correlation when compared to men ( $\mathrm{r}$ : 0.799).

The relationship between vertebral length and height in this study is fairly strong. The regression formula obtained in this study can be used to estimate height, especially in cases of mutilation or fire victims and other cases where only spinal bones, and no other long bones, are found.

There is a correlation between height and vertebral length. Regression formula to estimate height based on vertebral length:

$$
\begin{gathered}
Y=47.428+2.991 \mathrm{X}_{1}+2.13 \mathrm{X}_{2} \mathrm{~cm} \text { (Male) } \\
\mathrm{Y}=-32.496+3.800 \mathrm{X}_{1}+5.549 \mathrm{X}_{2} \mathrm{~cm}(\text { Female) } \\
\text { Y: Body Height, } \mathrm{X}_{1} \text { : Thoracal Length, } \mathrm{X}_{2} \text { : Lumbar Length }
\end{gathered}
$$

This regression formula can be used in estimating height when only spinal bones are found without other long bones.

\section{References}

1. Guillot EG, Tumonggor MK, Lansing JS, Sudoyo H, Cox MP. Climate change influenced female population sizes through time across the Indonesian archipelago. Hum Biol. 2013;85(1-3):135-52.

2. Algozi AM, Yudianto A. Height measurement based on sternal bone length adults. Folia Medica Indonesiana. 2006;42 (3):181-2.
3. Koesbardiati T, Yudianto A, Murti DB, Suyanto RA. Variasi genetik loci STR CODIS [THOI, TPOX] Manusia Gilimanuk [Pulau Bali]. Berkala Arkeologi. 2013;32(2):133-49.

4. France DL. Human and non human identification. USA: CRC Press Taylor \& Francis Group; 2009.

5. Lansing JS, Cox MP, de Vet TA, Downey SS, Hallmack B, Sudoyo H. An ongoing Austronesian expansion in Island Southeast Asia. J Athropological Archaeol. 2011;30(3): 262-72.

6. Sutriani, KT, Isnawati M. Perbedaan antara tinggi badan berdasarkan panjang ulna dengan tinggi badan aktual dewasa muda di kota semarang. Journal of Nutrition College. 2014;3(1):117-24.

7. Klein A, Nagel K, Gührs J, Poodendaen C, Püschel K, Morlock MM, et al. On the relationship between stature and anthropometric measurements of lumbar vertebrae. Sci Justice. 2015;55(6):383-7.

8. Oura P, Korpinen N, Niinimäki J, Karppinen J, Niskanen M, Junno J. Estimation of staturefrom dimensions of the fourth lumbar vertebra in contemporary middle-aged finns, Forensic Sci Int. 2018;292:71-7.

9. Kranioti E, Paine R. Forensic anthropology in Europe: an assessment of current status and application. J Anthropol Sci. 2011;89:71-92.

10. Guglielmi G, Diacinti D, van Kuijk C, Aparisi F, Krestan C, Adams JE. Vertebral morphometry: current methods and recent advances. Eur Radiol. 2008;18(7):1484-96. 